\title{
Applying Web-Based Technology in Developing Student Worksheets on Writing Local Culture Content Drama Script
}

\author{
Nurhayati \\ Department of Indonesian Language and Literature, Universitas Sriwijaya, Palembang, Indonesia \\ Tono Suwartono \\ Department of English Language Teaching, Universitas Muhammadiyah Purwokerto, Purwokerto, Indonesia \\ Agus Saripudin \\ Department of Indonesian Language and Literature, Universitas Sriwijaya, Palembang, Indonesia \\ Neneng Juwita \\ Department of Indonesian Language and Literature, Universitas Islam Negeri Raden Fatah, Palembang, Indonesia
}

\begin{abstract}
The purposes of this study were to identify the students' and teacher's needs for student worksheets for teaching local culture content drama scripts writing based on the verses of Sultan Abdul Muluk (SAM), to design a prototype of the worksheets, to obtain expert validation of the prototype, to determine the worksheets' practicality, and to examine the effectiveness of the developed worksheets. The research procedures were based on Plomp's model and Tessmer's modified model of Research \& Development. Data were collected employing multiple techniques. To obtain information on the student and teacher needs, questionnaires were administered and an interview was conducted. To ascertain the validity of the worksheets, an expert validation was carried out. To determine practicality of the worksheets, a small group evaluation was conducted, and questionnaires were administered. To examine the effectiveness of the worksheets, field tests of script writing were carried out. Results of the need analysis revealed that all students and teachers needed elearning-based student worksheets on drama scripts writing based on SAM verses. Based on expert validation, the developed worksheet was categorized as valid. Based on the small group evaluation, the worksheet was considered practical. Results of the field tests indicated that the worksheet was effective. The implication is that the worksheet is of great importance and, therefore, will likely become a major instructional material for teaching drama script writing based on SAM verses.
\end{abstract}

Index Terms — elearning, worksheets, cultural, drama, writing

\section{INTRODUCTION}

One of the skills that must be mastered by the $8^{\text {th }}$ year students in Indonesia is the skill of writing drama scripts. This is stated in one of the basic competencies in the Indonesian language subject under the Curriculum 2013 which is currently being implemented throughout the Archipelago. The ability to write drama scripts is needed because it can contribute to the student appreciation for drama arts. One way to improve one's appreciation for drama is through enhancing their ability to produce drama scripts. In fact, the eighth graders were still unable to write drama scripts with local content. The possible contributing factor is the particular intrinsic difficulty of writing this script type, i.e., the required use of archaic language and inclusion of bermas (a series of formulaic introductory expressions).

From an initial survey conducted with twenty students, $80 \%$ of them found it difficult to write drama scripts. One of the reasons for this difficulty was the absence of teaching materials that contained detailed steps for writing a drama script. A hundred percent of the students needed teaching materials that contained how to write drama scripts based on SAM verses completed with systematic writing practices. As many as $90 \%$ of students stated that it was very necessary to include elements of local culture, especially SAM verses. All students felt the need to preserve Dulmuluk's performing art. They considered writing Dulmuluk drama script is an opportunity that may not be missed. They would have felt proud if they had had the opportunity to write the script after completing a sufficient training. The students hoped that their scripts were selected for classroom drama performance.

Based on the interview on teaching drama script, the teacher divided students into various tasks in order to perform plays on stage. Some were assigned to act out as players, directors, and performers; others were in charge of costumes, make-up, and so on. Thus, the teacher did not ask all students to write a drama script. Thus, from the teacher's experience it can be concluded that not all students had the ability to write drama scripts well. The teacher only invited students who were considered capable of writing drama scripts in order to perform it in the classroom. 
The teacher also stated that there were not many teaching materials related to drama scripts writing. Moreover, the teaching materials for drama scripts writing concerning local culture such as the verses of Sultan Abdul Muluk (henceforth abbreviated as SAM) were not available yet. What was available has been just general drama scripts writing which was not based on SAM verses. The teacher explained that the Dulmuluk's performing art needed to be preserved. Students needed to know about the Dulmuluk performing art. Therefore, Dulmuluk drama scripts are needed because a drama script is one of the keys to a successful drama performance (Udomisor \& Tosin, 2013). The teacher also mentioned his expectation for a more concise drama writing material, step-by-step drama-script-writing instructions followed by examples, exercises, and drama script writing assessment rubric. Further, the teacher wanted online worksheets that were easily accessible at any time.

Concerning the worksheet, from the researcher's observations of the worksheets in circulation, it was found that the student worksheets gave no emphasis on learning process. The worksheets contained mainly material summaries. The material presented did not cover structured steps on how to form concepts and to achieve the final learning competency, namely writing a drama script. In addition, the existing worksheets are still in a printed form. This caused learning to be less effective and efficient despite today's online era.

From the results of teacher need assessment, it was known that the teacher suggested six important points. First, student worksheets should be digitalized in order that learning is conducted online. Second, the material provided should match better with the learning objectives. Third, the future worksheets should cover material on SAM verses such as who wrote, when they were written and the brief contents of the verses, and model of local cultural drama scripts. Fourth, the desired worksheets should give an emphasis on individual writing skill. Fifth, the worksheets should come with an assessment rubric and appropriate ways of evaluating drama scripts. Sixth, the worksheets should use language that can easily be understood by students.

In response to the curriculum demand, the absence of appropriate worksheets and the student and teacher need for such worksheet, a collaborative research-and-development study was conducted. The purpose was to create a student worksheets design (prototype) on the basis of students' and teacher's needs, to obtain a valid set of student worksheets based on an expert validation, to describe the practicality of the worksheets according to a small group evaluation, and to examine the effectiveness of the worksheets based on a field test.

\section{LITERATURE REVIEW}

In this section, three issues, i.e., elearning, student worksheet, and drama writing with local culture will be discussed.

\section{A. Elearning in Current Education}

Nowadays, the use of networks and information technology in the learning process is increasing rapidly, it can even be said that there is almost no learning process without the presence of technology and information (Anisimova et al., 2021; Belazoui et al., 2021; Padgett et al., 2021).

Language learning is no exception. It is inevitably affected by the use of information technology as evidenced by the implementation of online learning (Jurkovič, 2019; Thoms, 2020). Technological development offers practical benefits to anyone to get information through data on various computers in the world as long as they are connected to the internet network (Wen \& Wu, 2017; Zhang \& Dong, 2021).

Especially in the Covid-19 pandemic era, due to the closure of schools and colleges almost all academic learning activities across the world have been carried out online by applying educational technology (Hussein et al., 2020; Jesuiya \& Priyadarshani, 2020; Krelová et al., 2021; Lock \& Redmond, 2021). Elearning-based instruction, which makes use of ICT, can overcome learning difficulties caused by distance, geographic location, and time constraints (Mohan et al., 2015; Ali \& Algane, 2020). The use of online and communication technology positively can also influence the writing process. When the writing process is conducted online, there is a greater probability that students carry out writing assignments more enthusiastically and more efficiently (Boran et al., 2015; Shaaban, 2020).

The results of this study indicate students' positive perception about the usefulness of elearning. Elearning saves time and money. With online learning learners can access content anywhere and anytime. Elearning is also cost-effective; companies save a substantial amount on the travel and accommodation costs of both learners and instructors, as well as the venue and materials (Kultawanich et al., 2015; Nobles \& Paganucci, 2015).

The use of elearning provides opportunities for students to perform multimedia writing activities (Thowfeek \& Salam, 2014). The procedure that can be done to implement elearning is to develop website that meets instructional needs.

\section{B. Online Student Worksheet}

One type of instructional material that can help students in learning process is student worksheets. Various studies in both science and humanities show that students' abilities in various fields can improve through the use of student worksheets (Ayva, 2012; Kolomuç et al., 2012; Ulaş et al., 2012).

Student worksheet is a practical and useful teaching material in the learning process (Choo et al., 2011). Student worksheet is one type of teaching materials in which there are concrete steps that students must take in order to achieve learning goals (Y1ldırım et al., 2011). In addition, student worksheets have an important role in improving students' 
critical thinking. Student worksheets can be used in language learning and can cover various topics and work on various skills (Kasap, 2016; Majlesi, 2014). Student worksheets can enhance students' short story writing skills. Student worksheets can also improve students' interest and competency in drama script writing.

\section{Local Culture-Based Drama Script Writing}

According to the regulation issued by the Ministry of Education and Culture of Republic of Indonesia No. 58 Attachment III, teachers play an active role in promoting culture at schools(Peraturan Menteri Pendidikan Dan Kebudayaan Republik Indonesia Nomor 58 Tahun 2014 Tentang Kurikulum 2013 Sekolah Menengah Pertama/Madrasah Tsanawiyah [The Educa-Tion and Culture Ministry Regulation No. 58/ 2014 on Curriculum 2013 for Primary Schools], n.d.). They should provide an appropriate condition for interactive and inspirative learning and integrate local culture into classroom instruction. The purpose of such integration is to preserve local culture amidst the tremendous impact of globalization.

One way of integrating local culture is by incorporating local culture-based drama script writing into the Indonesian language and literature instruction. Local culture may perform a strategic function in character and identity building. Therefore, the inclusion of local culture should be conducted in the teaching of drama script writing. Through writing drama scripts, it is possible to build characters more comprehensively and optimally.

The process of drama script writing requires students to understand humans with the conflicts they experience. The problems of humans with humans, humans with nature, and humans with rulers can be explored through writing drama scripts. Drama scripts used as a source of character building for students are drama scripts that are compiled based on local culture.

There have been dozens of studies related to learning to write drama scripts in the last decade in Indonesia. These studies generally show that Indonesian students are weak in their ability to write drama scripts. Their weakness is that they find it difficult to describe place, situation, and characters as an introductory part of drama script. In addition, they find it difficult to develop dialogues based on the plots. The most daunting task faced by the students is constructing a script which retains the dynamics of text structure, i.e., setting development, conflict raising, climax attainment, and conflict resolution.

The drama script referred to in this research is one based on SAM verses. SAM verses are rhyming poems written by Raja Ali Haji in 1847 (Sham, 1993). This type of poem in Palembang area underwent a metamorphosis and became a performing art. The performing arts are known as 'Dulmuluk performing art' or just Dulmuluk. The Dulmuluk has its own typical style and, consequently, the drama script should accommodate that style. This stylistic feature takes the form of bermas, i.e., the introductory part of performance where characters walk in line onto the stage singing and dancing with a typical music accompaniment. To perform the Dulmuluk, of course, a typical style-bound Dulmuluk drama script is highly necessary and, therefore, the ability of students to write local cultural drama scripts is crucial.

\section{METHODOLOGY}

\section{A. Research Design}

This study is of research and development type which produces an output or product. The product developed in this study is elearning-based worksheets for drama scripts writing with local cultural content. This study integrated and modified two learning material development models, namely the Plomp's (Plomp \& Nieveen, 2013) learning material development model and the Tessmer's (Tessmer, 2015) modified development model. The modified steps consist of preliminary research, design and development of the prototype, and evaluation. The evaluation stage includes three stages, namely expert review, small group evaluation, and field test.

The major activity in the preliminary research is need analysis. This analysis is an initial stage of this study in the form of a survey to analyze the needs of students and teachers. The aim was to explore the necessity of student worksheets for the online teaching and learning of local cultural drama scripts writing.

The design stage was carried out by selecting the learning model adopted, the work steps taken, compiling a competency map, setting up the learning objectives, providing assignments, and developing the assessment criteria. The researcher then compiled a development design that included paper based and computer based. The paper-based design included an outline of the content of the material, a description of the material, a story board, and evaluation tools. The computer-based design included elearning programming in the form of a website to display worksheets. Meanwhile, the website address is www.lkpdelearning.com and the program developer was Mr. Saleh Irwandi who worked at PT Abbauf Mulia Konsultan Teknologi in Palembang, Indonesia.

The first stage of evaluation is expert validation. Expert validation was conducted by experts by giving their opinions to assess the validity of the worksheets being developed. Validation of the student worksheet covers three aspects, namely validity of content, accuracy of language, and suitability of media.

Validation of content eligibility was carried out by Prof. Dr. Mulyadi Eko Purnomo, a lecturer in language education master's study program, Faculty of Teacher Training and Education, Universitas Sriwijaya. The learning media aspect was validated by Mr. Novri Hadinata, a lecturer in The Faculty of Computer Science, University of Bina Dharma in Palembang. Validation of language accuracy was carried out by Sri Indrawati, Ph.D., a lecturer in Department of Language Education study program, Faculty of Teacher Training and Education, Sriwijaya University. 
The second stage of evaluation is small group evaluation. A small group evaluation was carried out to see the practicality of the student worksheets. The third stage of formative evaluation is field tests. Field test was administered to see the effectiveness of the worksheets. The research design applied in the field tests stage was the one group pretestposttest design experiment with a group of students. The research design is illustrated as follows.

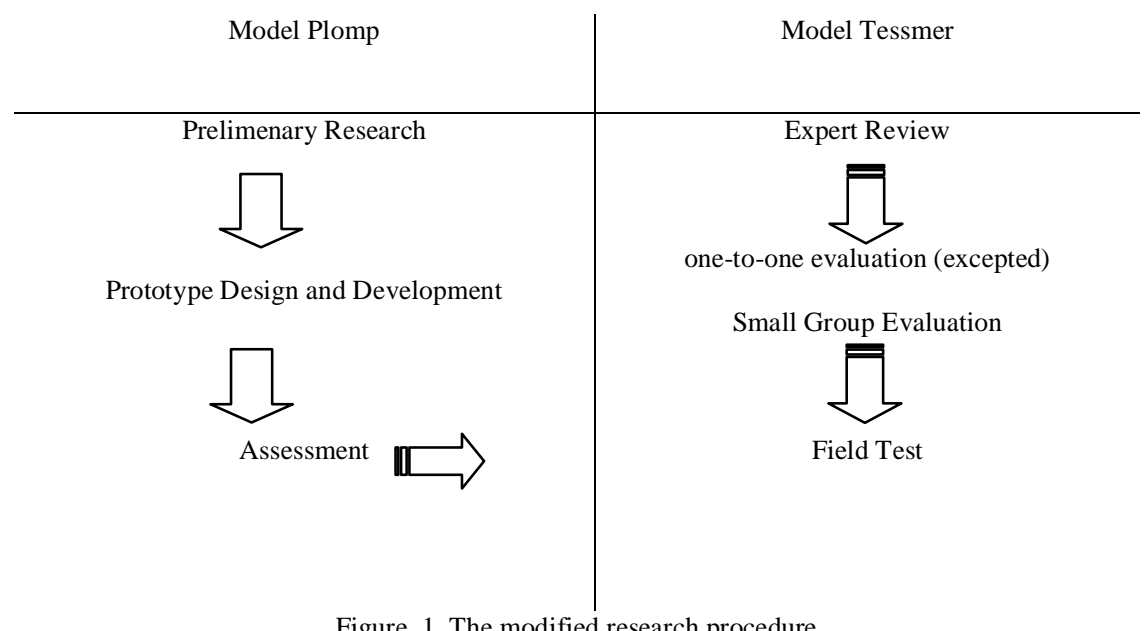

Figure. 1. The modified research procedure

\section{B. Techniques of Data Collection}

To obtain data related to the needs of students and teachers, questionnaires were administered and an interview was conducted. The questionnaire items dealt with students' experience in writing drama scripts, their expectations for teaching materials, and their views on local culture, especially one in the form of SAM verses. Interview was conducted with a teacher. The questionnaire comprised statements related to the teaching materials used by the teacher, the need for supporting teaching materials, and the weaknesses of the teaching materials used so far. Meanwhile, the interview included the main questions related to the teaching materials used by the teacher so far, the advantages of teaching materials, and their weaknesses.

To obtain data from expert validation, assessment sheets were used. The assessment components include content, instructional media, and language use. There are 11 components related to worksheet content, and a rating scale of 1 to 5 was used. The assessment components covered (1) clarity of learning objectives, (2) suitability of content with learning objectives and basic competencies, (3) suitability of content with-the exercises and the objectives, (4) suitability of examples with explanations. (5) accuracy of content organization, (6) novelty of the material, (6) validity of content (7) depth of material, (8) accuracy of references, (9) availability of motivation and attractiveness (10) suitability of content with student cognitive development, (11) validity of content.

The assessment component relates to the validity of instructional media including 11 components using 1 to 5 rating scale. The assessment components comprised (1) choice of font size and type, (2) presentation of graphics (tables, diagrams, graphs, (3) choice of visuals (pictures, photos, and sketches), (4) choice of colors (5) selection of illustrations (6) choice of icons, (7) consistency in using fonts, (8) overall attractiveness (9) interactiveness, (10) use of navigation (11) overall lay-out. The questionnaire given to the experts is divided into two sections. The first section contains an assessment table in the form of numbers on 1 to 5 rating scale. The second section contains a column of suggestions and comments on the developed worksheets from the experts.

The assessment related to language appropriateness included 10 components using 1 to 5 rating scale. They are: (1) spelling and punctuation accuracy, (2) editorial clarity and readability, (3) accuracy of examples and illustrations, (4) suitability of language styles with the target students, (5) grammatical accuracy, (6) accuracy of word choice, (7) clarity of language of instruction, (8) language properness, (9) cohesion between sentences, and (10) coherence between paragraphs.

In order to obtain data from small group evaluation, questionnaire technique was employed. The small group evaluation was carried out to capture the following: (1) whether the material provided is in accordance with the learning objectives; (2) whether the worksheets have sufficient information about the material provided; (3) whether the examples discussed in the student worksheets are sufficient; and (4) whether there was suitability between the material and exercises in the worksheets. In the questionnaire, a comment column was also provided so that students gave their opinions regarding the four questions.

To collect data from the field test, a writing-performance test was administered. In this test, the student participants were asked to write a drama script based on SAM verses. The test was conducted twice, i.e., before using the student worksheets (pretest) and after using the worksheets (posttest).

\section{Techniques of Data Analysis}


The data obtained from student need survey were tabulated in percentage. The data gained from interviews were described according to the questions asked. It is necessary to note that result of the student and teacher need analysis is presented earlier in the background section to highlight the significance of the study.

To determine the validity and practicality of the developed worksheets, the assessment criteria as seen in Table 1 was used. Average scores obtained from the 5-point scale assessment were converted to percentage score in the following four-interval categories table.

TABLE 1

CATEGORIES OF ASSESSMENT Result

\begin{tabular}{|l|l|l|l|}
\hline No & $\begin{array}{l}1-5 \text { Rating Scale } \\
\text { Score }\end{array}$ & Percentage Score & Category \\
\hline 1 & $4.3 \leq \mathrm{AR} \leq 5.0$ & $86 \leq \mathrm{AR} \leq 100$ & Extremely valid/practical \\
\hline 2 & $3.5 \leq \mathrm{AR}<4.3$ & $70 \leq \mathrm{AR}<86$ & Valid/practical \\
\hline 3 & $2.8 \leq \mathrm{AR}<3.5$ & $56 \leq \mathrm{AR}<70$ & Slightly valid/practical \\
\hline 4 & $1.0 \leq \mathrm{AR}<2.8$ & $00 \leq \mathrm{AR}<56$ & Invalid/impractical \\
\hline
\end{tabular}

To determine whether there was a significant difference between the mean scores of pre- and posttests, the t-test statistical analysis was conducted using SPSS 21 software. In this case, the paired sample t-test was employed. When the t-test proves a significant difference between the two mean scores, then it is assumed that there is a significant increase in students' ability to write drama script based on SAM verses attributed to the use of the developed worksheets.

\section{Research Subjects}

The current research involved a teacher who teaches the Indonesian language subject to grade VIII students at Lifeskill Teknologi Informatika Indo Global Mandiri Senior High School in Palembang, Indonesia. Twenty students participated in the need analysis and field tests, where nine of them were recruited for a small group evaluation. The 9 students represent low, medium, and high groups. Determination of low, medium, and high was based on their report card scores.

\section{RESULTS AND DisCUSSION}

\section{A. Prototype of the Worksheet}

This worksheet was designed using a web-enhanced course model, which is a model for using the internet to support the improvement of the quality of learning in class. The researchers used Macromedia Dreamweaver 8, Mozilla Firefox, 00webshot, and PHP programs. The menus contained in the elearning-based worksheets consist of: (1) homepage, (2) about the program, (3) objectives, (4) instructions, (5) material, (6) exercises, (7) assessment criteria, (8) collections manuscripts, (9) references, (10) bibliography, (11) glossaries, and (12) authors.

In this elearning-based worksheet design, there are four basic competencies contained in four exercises. These exercises are (1) practice in identifying the elements of drama, (2) practice in reviewing the structure and language rules of drama texts, (3) practice in interpreting verses read through both heuristic and hermeneutic techniques, and (4) practice in writing a drama script based on a verse.

There were five learning objectives that students had to achieve in this student worksheet, namely, (1) students are able to mention the elements of drama through reading local cultural drama scripts carefully, (2) students are able to examine drama structures through reading local cultural drama scripts carefully, (3) students are able to mention the linguistic rules of the local cultural drama text through reading the drama script correctly, (4) students are able to interpret SAM verses through heuristic and hermeneutic reading thoroughly, and (5) students are able to write drama scripts based on SAM verses through practicing activities giving attention to structure and rules of language. 


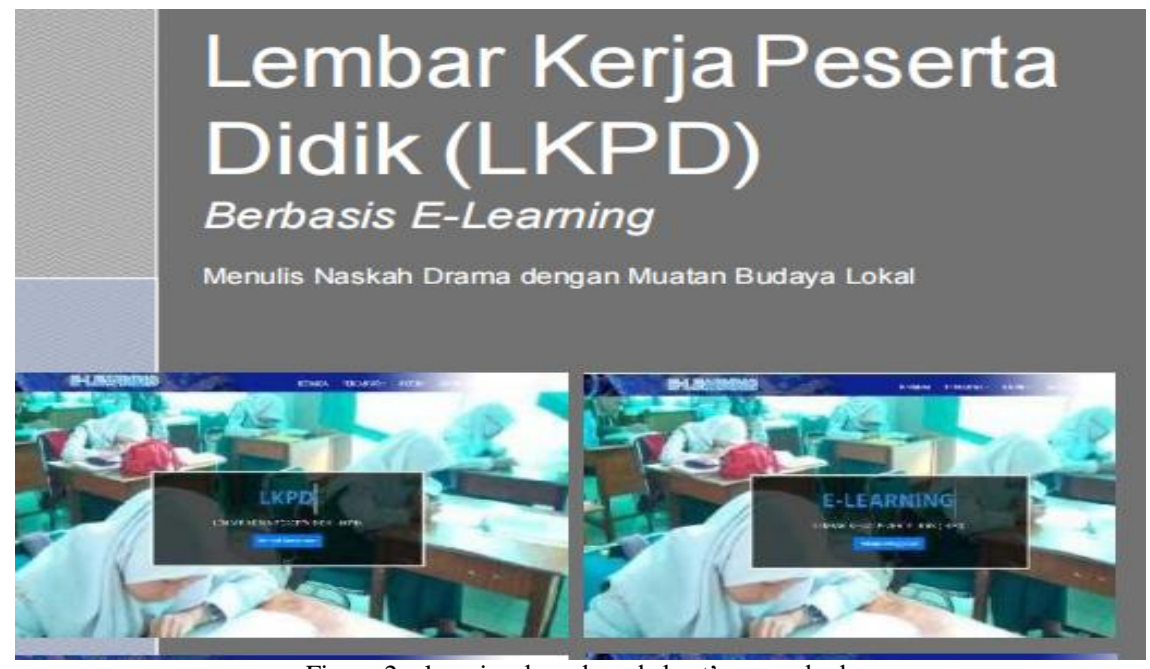

Figure 2. elearning-based worksheet's cover look

To be able to use this student worksheet there are several things that must be fulfilled by students, among others (1) availability of sufficient computer and internet facilities; (2) students' ability to operate computers well; (3) students' engagement in the learning process; and (4) the teacher's role as a guide, mediator, motivator, and facilitator.

\section{B. Expert Validation}

The following chart displays results of the expert validation on the validity of the developed worksheets.

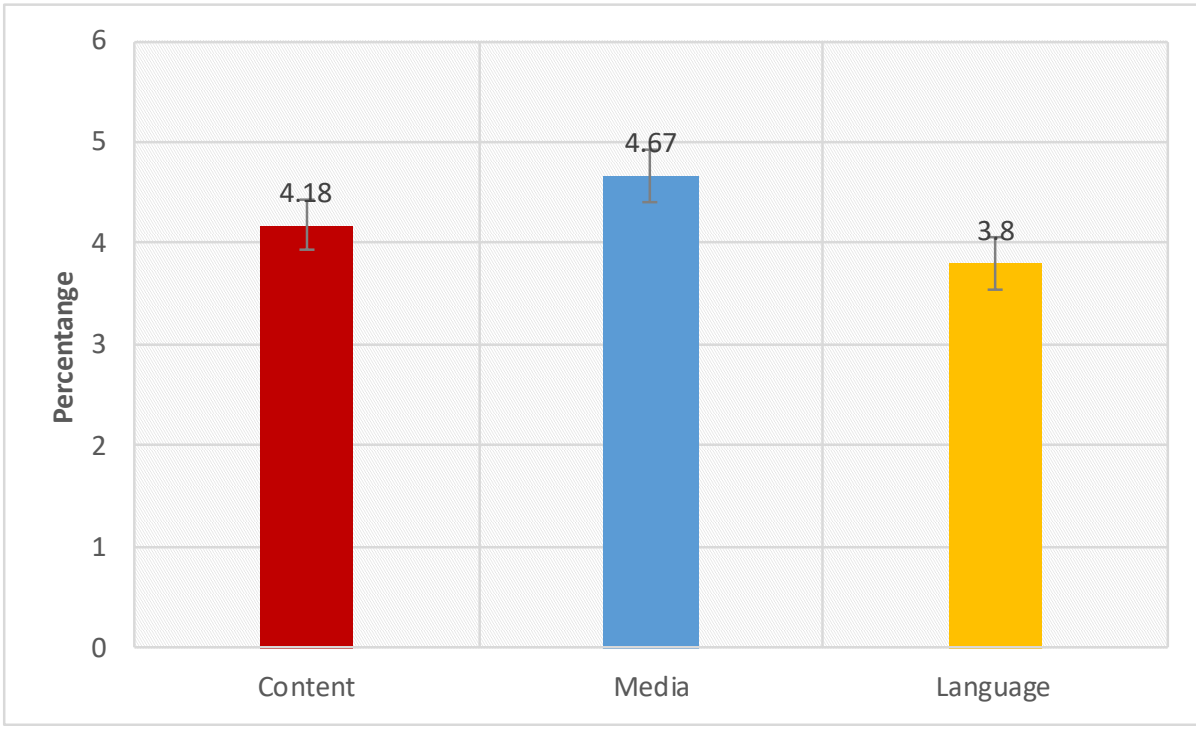

Figure 3. Expert validation results

Results of content validation provided the following information. Of the 11 assessment components, clarity of the formulation of learning objectives obtained score 4, suitability of material with learning objectives and basic competencies received score 4, suitability of exercises with the objectives and the material received score 4, systematicity of material presentation (coherence, logics, straightforwardness) obtained score 4, novelty of the material achieved score 5, depth of the material obtained score 4, accuracy of the references reached score 4, provision of motivation and attractiveness (colors and images) obtained score 5, and suitability with student intellectual development reached 4, validity of the material substance, examples of text and exercises obtained score 4, and suitability of examples with explanations obtained score 4 . The total score of content validation was 46 with an average score of 4.18 .

There were several suggestions given by the material validator in the comment's column provided. First, information about the character's personality should be made clearer by adding various sources. Second, examples of heuristic and hermeneutic interpretations should be enriched by adding more examples, and the three examples of turning verse into dialogue should be clarified in detail. With regard to media utilized in the worksheet, results of the media expert's validation gave the following information. Of the 11 assessment components, choice of font type and size got score 4 , presentation of graphics (tables, diagrams and graphs) scored 5, choice of visuals (pictures, photos, and sketches) obtained score 5 , choice of color scored 4 , use of illustrations obtained a score of 4 , choice of icons got a score of 4 , 
consistency in using font gained score 5, overall attractiveness scored 5, interactiveness scored 5, use of navigation scored 5, and the overall lay-out scored 5. Thus, the total score of media validation was 51 with an average score of 4.67.

The media validator provided three pieces of suggestion in the comment's space provided. Firstly, the "Forgot password" menu should be added by integrating it to the user's email address. Secondly, instructions for using the product should be placed in front of the start page, and thirdly, in the "Admin" menu, a search menu should be added to enable users to find student data.

Concerning language use, results of the language expert validation showed the following. Of the 10 components of the assessment, spelling and punctuation accuracy obtained score 3, editorial clarity and readability obtained score 4, accuracy of examples and illustrations obtained score 4, appropriateness of language styles with the target students scored 4, grammatical accuracy gained score 4, the accuracy of word choice got score 3, clarity of language of instructions scored 4, language properness (how proper the words/expressions are used) scored 5, cohesion scored 3, and coherence between paragraphs scored 4 . Thus, the total language evaluation score was 38 with an average score of 3.8 .

According to the language validator's comments, this worksheet was very useful in the learning process of drama scripts writing. It was hoped that this worksheet was able to raise the effectiveness of learning. The worksheet was written in clear and accurate language. However, the language validator suggested that accuracy in the use of grammar, spelling, choice of words be improved to achieve the targeted effectiveness.

Those three types of expert validations averaged 4.21. Consulting it to the referred categories table of assessment result, it equals to 84.2 , falling to the range of valid.

\section{Small Group Evaluation}

Results of the questionnaire showed that as many as $89 \%$ of the students agreed that the material was in concordance with the learning objectives, $78 \%$ of the students thought that there was sufficient information related to the material provided, $67 \%$ of the students believed that there were sufficient examples, and $78 \%$ of the students agreed that the exercises matched with the material. The average score of those four components was $78 \%$, which falls to the category of practical for use. Thus, it can be said that the elearning-based worksheets showed an agreement between the material and learning objectives. The elearning-based worksheets had sufficient information, material examples, and exercises to help students write drama scripts.

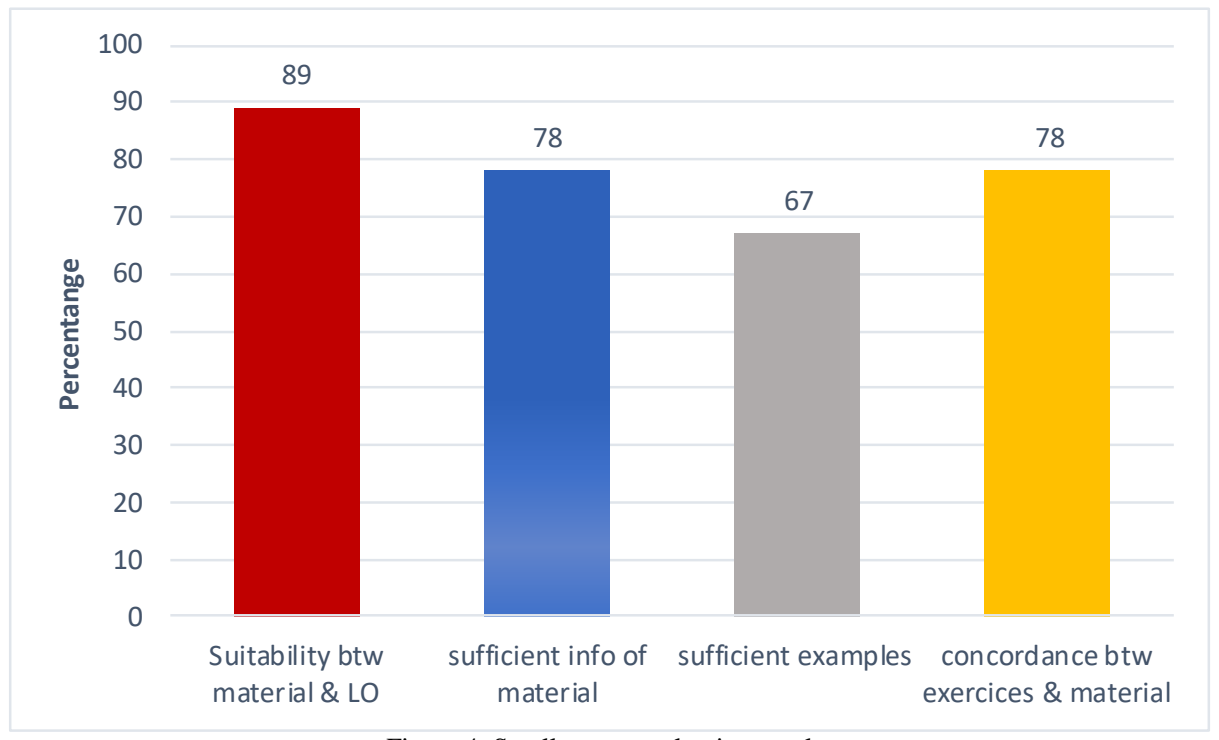

Figure 4. Small group evaluation results

Overall, the developed elearning-based worksheets were in line with the learning objectives. The learning objectives were that students are able to mention the elements of drama, are able to examine the structure and language rules of drama text, are able to interpret the verses read applying heuristic and hermeneutic techniques, and are able to write drama scripts based on SAM verses.

The developed elearning-based worksheets provided material that was easy to understand. The readability of the material was attributed to the use of effective sentences. The practicality of the elearning-based worksheets was made possible with the steps of writing drama scripts both in heuristic and hermeneutic aspects as well as writing complete scripts based on the assessment rubric. With readability of the material contained in the worksheets, students could easily do all exercises. Nevertheless, the developed elearning-based worksheets had drawbacks. Students thought they lacked practice in interpreting activities both heuristically and hermeneutically. There were only 2 examples of exercises provided in the worksheets. Therefore, it was necessary to add exercises that include interpretation of SAM 
verses.

\section{Field Tests}

Results of the field testing to determine the effectiveness of the worksheet have shown the following information. The highest score of the pretest was 70, while the highest score of the posttest was 87 . The average score of the pretest was 65.70 , while the average score of the posttest was 80.35 . The posttest average score increased by 14.65 . The standard deviation obtained from the pretest was 4.41, whereas the standard deviation obtained from the posttest was 4.25. The ability of students' drama scripts writing improved after the use of the developed worksheets. In addition, the pretest scores have shown greater variation compared to those of the posttest scores. This can be interpreted that the students' scores on the posttest were more homogeneous. Homogeneity could be attributed to the students' ability to write better drama scripts.

Furthermore, to determine whether the improvement of students' drama script writing ability before and after the use of the worksheet was significant, the t-test statistical analysis was carried out. Results of the paired sample t-test calculations using the SPSS software can be seen in the following table.

TABLE 2

SUMMARY OF THE PAIRED SAMPLE T-TEST

\begin{tabular}{|c|c|c|c|c|c|c|c|c|}
\hline & \multicolumn{5}{|c|}{ Paired Differences } & \multirow[t]{3}{*}{$\mathrm{t}$} & \multirow[t]{3}{*}{$\mathrm{df}$} & \multirow[t]{3}{*}{ Sig. (2-tailed) } \\
\hline & \multirow[t]{2}{*}{ Mean } & \multirow[t]{2}{*}{ Std. Deviation } & \multirow[t]{2}{*}{ Std. Error Mean } & \multicolumn{2}{|c|}{ 95\% Confidence Interval of the Difference } & & & \\
\hline & & & & Lower & Upper & & & \\
\hline Posttest-Pretest & 14.65 & 6.43 & 1.44 & 11.64 & 17.66 & 10.19 & 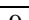 & 00 \\
\hline
\end{tabular}

As can be seen from Table 2, from the pretest to posttest the average score increased by 14.65 , the standard deviation $=6.43$, and the sig value (2-tailed) $=0.00$. This means there was a significant difference in average scores of students' drama script writing ability between before and after use of the elearning-based worksheets developed by the researchers. This was based on the fact that the sig value (2-tailed) $=0.00$ was smaller than the alpha value $=0.05$. Thus, it can be concluded that the developed elearning-based worksheets were effective to be used as a learning support for teaching local cultural content drama scripts writing.

The elearning-based worksheet for teaching drama scripts based on SAM verses are ones that are used as a complement to and support for textbooks in use. This worksheet was developed based on results of the analysis of teachers' and students' needs. The student worksheet was designed systematically. The most important thing is that the student worksheet contained practice after practice in interpreting verse both in heuristic and hermeneutic steps. These two steps were keys to the future effectiveness of this developed worksheet.

The worksheets were also equipped with examples and steps to interpret verses, steps to write a drama script based on the verse, assessment rubric, and of course developed on the basis of the competencies that students must achieve. The development of the skill of writing drama scripts, especially ones based on SAM verses, whose language is very archaic, take time and a lot of effort. This long process required students' and teachers' patience. Careful planning and preparation were also needed.

Moreover, this student worksheet can be used by students with or without the teacher's presence or guidance. First, the worksheets were designed in a concrete and detailed manner, assisted by examples and organized in language that is easy for students to understand. Various studies on student worksheets also have revealed the importance of worksheets which provide examples of expected skills and training about the skills.

Student worksheets developed based on elearning can help students do their learning activities anytime and anywhere. Thus, activities to understand material related to SAM verses, steps as well as practice after practice can be done without being limited by space and time. Students experienced interacting with verses, understood theories and practice according to their respective abilities and desires.

\section{CONCLUSION}

Results of the identification of the student and teacher needs at Lifeskill Teknologi Informatika Indo Global Mandiri Senior High School in Palembang showed that both the students and the teacher needed a support in the form of elearning-based worksheets to learn to write drama scripts based on SAM verses. This need was due to the unavailability of worksheets to facilitate the learning process of writing drama scripts based on the verses. On the basis of the need analysis, this student worksheet was developed through preparation and exploration, to create the prototype of the student worksheet. The worksheet was further developed into the final version, through evaluation to determine their validity, practicality, and effectiveness. The worksheet was declared by the validation experts as valid in terms of the content, language, and learning media. Thus, the worksheet was considered feasible for use in learning to write SAM-based drama scripts. Furthermore, the worksheet was categorized as practical based on the results of the small group evaluation. Through experiments with the one-group pretest-posttest design it was concluded that the worksheet developed was effective. The effectiveness of this student worksheet was made possible by the strengths of the student worksheet itself. Firstly, the worksheet uses language that is easy for students to understand. Secondly the worksheet was developed in line with the basic competencies and learning objectives to be achieved. Thirdly, the worksheet was 
equipped with examples of how to write a drama script part by part. Fourth, the worksheet was equipped with practice after practice accompanied by assessment rubric so as to help the students and the teacher in the assessment process. Finally, the worksheet was equipped with instructions for each section to assist students to do the writing practices.

Based on the research results, a major suggestion can be made. Teachers, especially the Indonesian language subject teachers, can use the developed worksheets because they have gone through a series of scientific inquiries (expert validation, field tryout, and tests of effectiveness). Tryout and tests of the developed worksheets were administered to students on a limited basis, i.e., students at Lifeskill Teknologi Informatika Indo Global Mandiri Senior High School in Palembang, Indonesia. Therefore, development of this student worksheet needs to be implemented on a wider scale to other groups of students with characteristics and needs probably different from those involved in the current study. By so doing, this developed worksheet is expected to be more reliable due to adequate supporting data. One obvious weakness of this study is that the field tryout was not conducted in an experimental design that involves control groups. Consequently, threat of bias may still remain. The current study tried out the developed worksheet to a single group of students (class) through one group pretest-posttest design experiment.

\section{ACKNOWLEDGEMENTS}

The authors gratefully acknowledge the financial support through the Professional Excellence Research scheme in Universitas Sriwijaya, South Sumatera, Indonesia, funded under the "Budget Implementation List" Grant.

\section{REFERENCES}

[1] Ali, R., \& Algane, M. A. A. A. (2020). Teaching english literacy in the time of COVID-19 pandemic in higher education: A case study in saudi qassim university. Multicultural Education, 6(5), 204-215. Retrieved July 21, 2020, from https://doi.org/10.5281/zenodo.4374526

[2] Anisimova, T., Ganeeva, A., \& Sharafeeva, L. (2021). Development of digital skills and engineering thinking in students as part of the digital summer project. International Journal of Engineering Pedagogy (IJEP), 11(2), 69-81.

[3] Ayva, O. (2012). Developing students' ability to read, understand and analyze scientific data through the use of worksheets that focus on studying historical documents. 4th World Conference On Educational Sciences (WCES-2012) 02-05 February 2012 Barcelona, Spain, 46, 5128-5132. Retrieved August 1, 2020, from https://doi.org/10.1016/j.sbspro.2012.06.395

[4] Belazoui, A., Telli, A., \& Arar, C. (2021). Web-based learning under tacit mining of various data sources. International Journal of Emerging Technologies in Learning (IJET), 16(16), 153-168.

[5] Boran, K., Boran, S., Bullington, T., Bynum, D., Davis, A., Gardner, J., \& Meek, J. (2015). Online writing instruction task force. Department of Writing and Rhetoric University of Mississippi, 27.

[6] Choo, S. S. Y., Rotgans, J. I., Yew, E. H. J., \& Schmidt, H. G. (2011). Effect of worksheet scaffolds on student learning in problem-based learning. Advances in Health Sciences Education, 16(4), 517. Retrieved July 1, 2021, from https://doi.org/10.1007/s10459-011-9288-1

[7] Hussein, E., Daoud, S., Alrabaiah, H., \& Badawi, R. (2020). Exploring undergraduate students' attitudes towards emergency online learning during COVID-19: A case from the UAE. Children and Youth Services Review, 119, 105699. Retrieved January 3, 2021, from https://doi.org/10.1016/j.childyouth.2020.105699

[8] Jesuiya, D., \& Priyadarshani, H. D. C. (2020). Impact on online teaching learning process during covid-19: With reference to faculty of education, the open university of Sri Lanka. Retrieved September 13, 2021, from http://ir.lib.seu.ac.lk/handle/123456789/5137

[9] Jurkovič, V. (2019). Online informal learning of English through smartphones in Slovenia. System, 80, 27-37. Retrieved January 29, 2020, from https://doi.org/10.1016/j.system.2018.10.007

[10] Kasap, B. (2016). A case study on the analysis of the worksheets used in a language preparatory school in higher education. International Journal of Languages' Education, 1, 36-36. Retrieved February 5, 2021, from https://doi.org/10.18298/ijlet.643

[11] Kolomuç, A., Özmen, H., Metin, M., \& Açışl1, S. (2012). The effect of animation enhanced worksheets prepared based on 5E model for the grade 9 students on alternative conceptions of physical and chemical changes. Procedia - Social and Behavioral Sciences, 46, 1761-1765. Retrieved July 21, 2020, from https://doi.org/10.1016/j.sbspro.2012.05.374

[12] Krelová, K. K., Berková, K., Krpálek, P., \& Kubišová, A. (2021). Attitudes of czech college students toward digital literacy and their technical aids in times of COVID-19. International Journal of Engineering Pedagogy (IJEP), 11(4), $130-147$.

[13] Kultawanich, K., Koraneekij, P., \& Na-Songkhla, J. (2015). A Proposed model of connectivism learning using cloud-based virtual classroom to enhance information literacy and information literacy self-efficacy for undergraduate students. The Proceedings of 6th World Conference on Educational Sciences, 191, 87-92. Retrieved March 22, 2021, from https://doi.org/10.1016/j.sbspro.2015.04.394

[14] Lock, J., \& Redmond, P. (2021). Embedded experts in online collaborative learning: A case study. The Internet and Higher Education, 48, 100773. Retrieved July 21, 2020, from https://doi.org/10.1016/j.iheduc.2020.100773

[15] Majlesi, A. R. (2014). Finger dialogue: The embodied accomplishment of learnables in instructing grammar on a worksheet. Journal of Pragmatics, 64, 35-51. Retrieved July 21, 2020, from https://doi.org/10.1016/j.pragma.2014.01.003

[16] Mohan, D., Paramskas, D., \& Sanders, A. (2015). Online courses for second and foreign language learning: Principles of design and delivery. Teaching and Learning Innovations, 17. Retrieved September 13, 2021, from https://journal.lib.uoguelph.ca/index.php/tli/article/view/3126

[17] Nobles, S., \& Paganucci, L. (2015). Do digital writing tools deliver? Student perceptions of writing quality using digital tools and online writing environments. Computers and Composition, 38, 16-31. Retrieved August 21, 2021, from https://doi.org/10.1016/j.compcom.2015.09.001

[18] Padgett, C., Moffitt, R. L., \& Grieve, R. (2021). More than words: Using digital cues to enhance student perceptions of online 
assignment feedback. The Internet and Higher Education, 49. Retrieved June 7, 2021, from https://doi.org/10.1016/j.iheduc.2020.100789

[19] Peraturan Menteri Pendidikan dan Kebudayaan Republik Indonesia Nomor 58 Tahun 2014 Tentang Kurikulum 2013 Sekolah Menengah Pertama/Madrasah Tsanawiyah [The Educa-tion and Culture Ministry Regulation No. 58/ 2014 on Curriculum 2013 for Primary Schools].

[20] Plomp, T., \& Nieveen, N. (2013). Educational design research: An introduction. in T. Plomp \& N. Nieveen (eds.) Educational Design Research. Netherlands institute for curriculum development (SLO). 10-51.

[21] Shaaban, S. S. A. (2020). TEFL professors' e-learning experiences during the COVID 19 pandemic. European Journal of Foreign Language Teaching, 5(1), Article 1. Retrieved April 25, 2021, from https://doi.org/10.46827/ejfl.v5i1.3202

[22] Sham, A. H. (1993). The Poems of Raja Ali Haji. Languages and Literature Council, The Ministry of Education of Malaysia.

[23] Tessmer. (2015). Planning and conducting formative evaluations: Improving the quality of education and training. Routledge.

[24] Thoms, J. J. (2020). Re-envisioning L2 hybrid and online courses as digital open learning and teaching environments: Responding to a changing world. 1(1), 86-98.

[25] Thowfeek, M. H., \& Salam, M. (2014). Students' assessment on the usability of e-learning websites. Procedia - Social and Behavioral Sciences, 141, 916-922. Retrieved April 21, 2021, from https://doi.org/10.1016/j.sbspro.2014.05.160

[26] Udomisor, I., \& Tosin, N. Y. (2013). Dramatic script writing and its effect on the performance of actors and actresses in nollywood films. Journal of Arts and Design Studies, 13(9), 23-30. Retrieved December 21, 2020, from https://iiste.org/Journals/index.php/ADS/article/view/8081

[27] Ulaş, H., Sevim, O., \& Tan, E. (2012). The effect of worksheets based upon 5e learning cycle model on student success in teaching of adjectives as grammatical components. Procedia - Social and Behavioral Sciences, 31, 391-398. Retrieved July 21, 2021, from https://doi.org/10.1016/j.sbspro.2011.12.072

[28] Wen, J., \& Wu, W. (2017). Multi-interactive teaching model of college english in computer information technology environment. International Journal of Emerging Technologies in Learning (IJET), 12(12), 79-90.

[29] Wiyono, K. (2015). Pengembangan model pembelajaran fisika berbasis ICT pada implementasi kurikulum 2013 [Developing ICT-based learning model in physics in the implementation of 2013 curriculum]. Jurnal Inovasi Dan Pembelajaran Fisika, Vol 2, No 2 (2015): Jurnal Inovasi dan Pembelajaran Fisika, 123-131.

[30] Yildırım, N., Kurt, S., \& Ayas, A. (2011). The effect of the worksheets on students' achievement in chemical equilibrium. Journal of Turkish Science Education, 8(3), 44-58.

[31] Zhang, H., \& Dong, B. (2021). Design and performance analysis of a training mode for digital media majors. International Journal of Emerging Technologies in Learning (IJET), 16(17), 149-163.

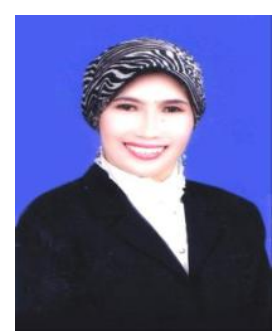

Nurhayati is a professor in the field of Indonesian Language and Literature Education. She teaches at the Indonesian Language and Literature Study Program, Teacher Training and Education Faculty, Universitas Sriwijaya, Indonesia. Various studies have been carried out, especially in the field of local performing arts which are almost extinct. She has also written many articles in various national and international journals. She actively presents the results of her research at various international seminars in Germany, Italy, the United States, Japan, Singapore and Malaysia as well as throughout Indonesia. She also wrote books related to the study of local literature and drama, for example stylistic studies, tourism literature, and spice literature, and Dulmuluk performing arts. She is also one of the assessors for accreditation under the National Accreditation Board for Higher Education. She has also trained in-service teachers, especially Indonesian language teachers since 2013. (email: nurhayati@fkip.unsri.ac.id).

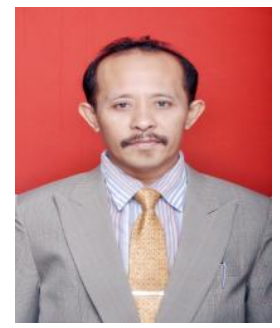

Tono Suwartono is an Associate Professor of TESOL with English Language Teaching Department at Universitas Muhammadiyah Purwokerto, Central Java Province, Indonesia. He has conducted countless researches, extensively published articles in national, international, as well as internationally reputed journals. $\mathrm{He}$ has travelled to many parts over the globe to present papers in conferences and publish them in proceedings. He has also productively written reference books and monographs. He has trained thousands of teachers nationwide. Besides working for the National Supervising Team in the implementation of School National Examination and Teacher Certification Program, he also sits in the editorial team and serves as a peer reviewer for several journals within Indonesia and beyond, including Arab World English Journal, Athens Journal of Philology (Greece), and Technium Social Sciences Journal (Romania). His main interests include: TEFL/TESOL and teacher training and education. (email: suwartononewton@ gmail.com).

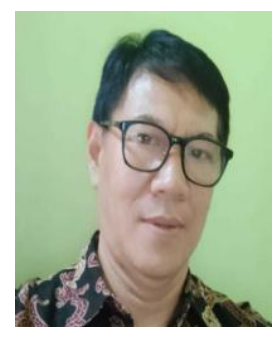

Agus Saripudin is a doctor in the field of Indonesian Language and Literature Education. He has been teaching at the Indonesian Language and Literature Study Program, Teacher Training and Education Faculty, Universitas Sriwijaya, Indonesia. A number of studies have been conducted, ranging from studies on literature (such as Dulmuluk performing arts) to studies on Indonesian language teaching. He also has teamed with other lecturers in carrying out a number of community services in schools, with regards to the implementation of the new curriculum. He has also participated in the in-service teacher training especially for Indonesian language teachers since 2016. (email: agus_saripudin@fkip.unsri.ac.id). 


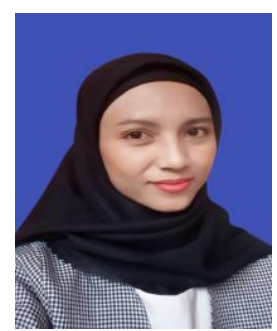

Neneng Juwita holds a master's degree in the field of Indonesian Language and Literature Education. She has been teaching at the English Language Study Program, Faculty of Tarbiyah and Teacher Training, Universitas Islam Negeri Raden Fatah Palembang, Indonesia. (email: nengjuwita55@ gmail.com). 